\title{
INVESTIGASI KEJADIAN LUAR BIASA HEPATITIS A DI KOTA DEPOK
}

\author{
Rahmat Saputra $^{1}$, Nurhayati A Prihartono ${ }^{2}$, Dwi Oktavia TL Handayani ${ }^{3}$, Yeni Devita ${ }^{4}$ \\ ${ }^{1,2}$ Program Studi Magister Epidemiologi Terapan Fakultas Kesehatan Masyarakat Universitas Indonesia \\ ${ }^{3}$ Dinas Kesehatan Provinsi DKI Jakarta \\ ${ }^{4}$ Sekolah Tinggi Ilmu Kesehatan Payung Negeri Pekanbaru \\ Email: ameq_jazzer@icloud.com
}

\section{Diterima: Juni 2021, Diterbitkan: Juni 2021}

\begin{abstract}
ABSTRAK
Hepatits A masih menjadi Kejadian Luar Biasa (KLB) secara nasional di Indonesia. Berdasarkan hasil Riskesdas 2018, angka kejadian hepatitis A mencapai 0,39. Kota Depok Jawa Barat juga menjadi daerah dengan KLB hepatitis A. Tujuan penelitian ini untuk mengetahui gambaran faktor risiko yang berpengaruh pada kejadian luar biasa (KLB) hepatitis A di Kota Depok Tahun 2019. Jenis penelitian yang digunakan adalah penelitian observasional analitik dengan menggunakan rancangan case control. Populasi penelitian sebanyak 705 responden. Terdiri dari 318 kasus dan 387 kontrol. Data faktor risiko diperoleh dari kuesioner yang diberikan kepada responden di SMPN 20 Depok, warga RT 01 dan RT 02/RW 01, RT 3/RW 02 Kelurahan Rangkapan Jaya dan Pesantren Petik. Kuisioner berasal dari sumber pedoman penanggulangan KLB Kementerian Kesehatan dengan modifikasi pertanyaan. Faktor risiko yang mempengaruhi KLB Hepatitis A di Kota Depok adalah sumber air minum isi ulang, kebiasaan tidak CTPS sebelum makan, kebiasaan tidak CTPS setelah BAB dan prilaku makan/minum menggunakan peralatan bersama. Untuk sumber KLB Hepatitis A di Kota Depok belum dapat diketahui dengan pasti akan tetapi penyebabnya diduga akibat paparan yang terjadi dalam waktu yang bersamaan (common source). Hal ini didukung dengan kurva epidemik yang berbentuk point source.
\end{abstract}

Keyword: Kejadian Luar Biasa, Hepatitis A

ABSTRACT

Hepatitis A is still an extraordinary event (KLB) nationally in Indonesia. Based on the results of Riskesdsa 2018, the incidence of hepatitis A reached 0.39. The city of Depok, West Java, is also an area with an outbreak of hepatitis A. The purpose of this study is to describe the risk factors that influence the usual occurrence (outbreak) of hepatitis A in Depok City in 2019. The type of research used is an analytical observational study using a case control design. The research population was 705 respondents. Consisting of 318 cases and 387 controls. Risk data factors were obtained from questionnaires given to respondents at SMPN 20 Depok, residents of $R T 01$ and RT 02/RW 01, RT 3/RW 02, Rangapan Jaya Village and Pesantren Petik. The questionnaire comes from the source of guidelines for handling outbreaks of the Ministry of Health with modified questions. The risk factors that affect the hepatitis A outbreak in Depok City are refill drinking water sources, the habit of not using CTPS before eating, the habit of not using CTPS after defecating and eating/drinking behavior using shared utensils. The source of the Hepatitis A outbreak in Depok City cannot be known with certainty but it will be suspected that the consequences occurred at the same time (general sources). This is supported by an epidemic curve in the form of a point source.

Keywords: Extraordinary Events, Hepatitis A 


\section{PENDAHULUAN}

Penyakit Hepatitis A merupakan sebuah penyakit infeksi hati yang disebabkan oleh virus hepatitis A (Aryana et al., 2014). hepatitis A memiliki masa inkubasi selama 18 - 50 hari (Suni, 2019). Gejala yang ditimbulkan dari hepatitis A antara lain adalah mual, muntah, nafsu makan berkurang, demam dengan suhu lebih dari $39^{\circ} \mathrm{C}$, adanya perubahan warna kulit, kuku, dan mata yang menjadi kuning serta urine yang berwarna kuning kecokelatan (Hikmah et al., 2018). Angka kejadian Hepatitis A di Indonesia mencapai 0,39\% (Riskesdas, 2018). Hasil ini menurun dari laporan Riskesdas 2013 yaitu 1,2 \% (Riskesdas, 2013). Walaupun ada penurunan dengan angka kejadiannya, namun masih ditemukan Kejadian Luar Biasa (KLB) untuk penyakit hepatits A (Harisma et al., 2018). KLb ini juga terjadi di kota Depok Provinsi Jawa Barat.

Tanggal 12 November 2019 Dinas Kesehatan Kota Depok terima telepon dari Puskesmas Kelurahan Rangkapan Jaya, terdapat siswa yang terindikasi hepatitis A di SMPN 20 Depok sebanyak 6 siswa. Tanggal 13 November 2019 Puskesmas Kelurahan Rangkapan Jaya melakukan investigasi ke SMPN 20 Depok, didapatkan informasi 105 siswa absen dan 10 siswa dirawat di RS. Tanggal 14 November 2019 Puskesmas Kelurahan Rangkapan Jaya investigasi lanjutan ditemukan kasus tambahan 16 orang penderita hepatitis A (8 orang dirawat di RS dan 8 orang berobat ke klinik dan Puskesmas). Tanggal 18 November 2019 Dinas Kesehatan Kota Depok melakukan investigasi lanjutan ditemukan 72 siswa dengan gejala hepatitis A hasilnya 51 positif. Tanggal 20 November 2019 Dinas Kesehatan Kota Depok dan Dinas Kesehatan Provinsi Jawa Barat memastikan adanya KLB di SMPN 20. Tanggal 21 November 2019 Kementerian Kesehatan menerima laporan adanya peningkatan Kasus hepatitis A di Kota Depok.
Tanggal 21 November 2019 Tim Gerak Cepat (TGC) Kementerian Kesehatan bersama Dinas Kesehatan Kota melakukan investigasi langsung ke SMPN 20 Kota Depok dengan hasil sebagai berikut: terdapat informasi terkait adanya kasus hepatitis A di SMPN 20 Kota Depok dimana sejak bulan November awal banyak siswa yang tidak masuk sekolah, dan teridentifikasi ada 103 kasus Hepatitis A. Pada tanggal 22 November 2019, sementara didapatkan data 138 kasus klinis Hepatitis A, BBTKL PP Jakarta mengambil 15 sampel hasil 1 positif atas nama IJ (diduga index case). Tanggal 22 November TGC gabungan melakukan investigasi terhadap index case yaitu seorang OB yang sekaligus menjadi penjual es di sekolah, yang beralamat di Desa Tajur Halang, Kec.Tajur Halang Kab. Bogor dengan hasil Penyelidikan Epidemiologi sebagai berikut: pada tanggal 5 November 2019 sudah merasa tidak enak badan, meriang dan badan terasa lemah. Pada tanggal 7 November 2019 yang bersangkutan ijin pulang ke rumah, tanggal 14 November 2019 berobat ke klinik Pratama Santa Teresa, karena merasa makin lemah, mual dan kencing berwarna kuning tua seperti air teh, dilakukan pemeriksaan laboratorium akan tetapi tidak diperiksa Hepatitis A Vyrus (HAV). Riwayat pada keluarga dan tetangga sekitar tidak ada yang menderita sakit yang sama, tidak ada riwayat bepergian lain wilayah, dan tidak ada riwayat kontak dengan penderita hepatitis. Kasus tersebut selama bekerja sebagai Office Boy di SMPN 20 Kota Depok, juga berjualan es di kantin sekolah. Es tersebut berasal dari distributor di Jl. Mandor Basar RT 02/RW 01 Kelurahan Rangkapan Jaya Kecamatan Pancoran Mas Kabupaten Depok. Pihak distributor tersebut telah diambil sampel darah. Dilakukan pengambilan sampel darah dan rectal swab: hasil HAV positif baik IgM dan IgG, PCR negatif.Tim TGC gabungan melakukan pelacakan kasus ke lapangan karena adanya 
laporan dari RT 01 dan RT $02 /$ RW 01 berlokasi sekitar SMPN 20 Depok bahwa ada kasus tambahan. Oleh karena itu Subdit Surveilans Kementerian Kesehatan RI menurunkan alumni FETP Universitas Indonesia untuk memperkuat investigasi yang lebih komprehensif. Investigasi oleh tim FETP Universitas Indonesia dilakukan mulai tanggal 26 November - 11 Desember 2019.

Dinas Kesehatan Kota Depok tanggal 27 November mendapat laporan dari petugas surveilans Puskesmas Kelurahan Rangkapan Jaya bahwa ada 21 warga terindikasi hepatitis A, kemudian Dinas Kesehatan Kota Depok bersama FETP Indonesia dan tim FETP UI melakukan investigasi dan berkolaborasi dengan BBTKL PP Jakarta melakukan penelusuran kasus warga dan mengambil serum darah yang diduga menderita hepatitis A di RT 01 dan 02 dari RW 1 di Kelurahan Rangkapan Jaya. Berdasarkan investigasi tersebut ditemukan bahwa salah satu warga yang yang paling awal mengalami gejala sakit pada lokus warga (Ibu M) ialah Bapak Y (40 tahun), diduga penularan terjadi saat ada acara kumpul bersama 1 RT di Bogor pertengahan oktober lalu. Beliau mengalami sakit kuning dan makan bersama warga lainnya. Ibu M merupakan salah satu warga kampong grogol yang sakit pertama kali yakni tanggal 3 November 2019, beliau yang memiliki Koyak (tempat penampungan aliran pembuangan jamban, air cuci piring, cuci baju) yang berbentuk kolam beralaskan tanah tanpa penutup di atasnya. Ibu $\mathrm{M}$ memiliki anak yang sekolah di SMPN 20 (siswi A) yang juga menderita sakit tanggal 15 November.

Pada tanggal 29 November 2019 jam 10.30 WIB, seorang staf pengajar pesantren di Pesantren Teknologi Informasi dan Komunikasi (Petik) yang berjarak 200 meter dari SMPN 20 Kota Depok melaporkan ke Dinas Kesehatan Depok ada 9 orang terindikasi hepatitis A. Kemudian, FETP Indonesia dan tim FETP UI melakukan investigasi pada tanggal 29 November 2019 jam 15.30 WIB, ditemukan data sebagai berikut: kasus pertama di pesantren ini adalah siswa dengan inisial AD dengan gejala awal sakit tanggal 13 November 2019. Kasus kedua pada pesantren ini, adalah siswa dengan inisial AA dengan gejala awal sakit tanggal 15 November 2019. AD rutin berbelanja jajanan cilok, nasi goreng, nasi uduk, di luar pesantren tepatnya di depan SMPN 20 Kota Depok. Jajanan tersebut dibeli dan dimakan bersama rekanannya di pesantren. Setelah dilakukan penelusuran lanjutan di ketahui bahwa kasus dengan gejala pertama muncul pada tanggal 3 November 2019. Total murid pesantren Petik yang suspek Hepatitis A berjumlah 13 orang. Sampai tanggal 2 Desember 2019, kumulatif kasus sebanyak 318 kasus, terdiri dari 249 kasus siswa SMPN 20 Depok, warga RT 01 dan RT 02/RW 01, RT 3/RW 02 Kelurahan Rangkapan Jaya 56 dan pesantren Petik 13.

Berdasarkan latar belakang diatas penulis ingin mengetahui mengetahui gambaran epidemiologi suspek penyakit Hepatitis A dan faktor risiko yang berpengaruh pada kejadian luar biasa (KLB) hepatitis A di Kota Depok Tahun 2019 yang meliputi gambaran kejadian menurut orang, tempat, dan waktu, gambaran sumber penularan, factor risiko, dan memberikan rekomendasi terkait masalah tersebut.

\section{METODE PENELITIAN}

Jenis penelitian yang digunakan adalah penelitian observasional analitik dengan menggunakan rancangan case control. Data faktor risiko diperoleh dari kuesioner yang diberikan kepada responden di SMPN 20 Depok, warga RT 01 dan RT 02/RW 01, RT 3/RW 02 Kelurahan Rangkapan Jaya dan Pesantren Petik. Kuisioner berasal dari sumber pedoman penanggulangan KLB Kementerian Kesehatan dengan modifikasi pertanyaan. Responden terdiri dari kasus dan 
kontrol yang terdiri dari siswa SMP, warga dan pesantren Petik. Kriteria untuk kasus adalah kasus confirm hepatitis A, kasus probable hepatitis A dan kasus suspect hepatitis A. sedangkan kriteria untuk control adalah responden sehat atau tidak adanya gejala gejala khas seperti demam, kulit kuning, sklera mata kuning (jaundice) air kencing berwarna teh dan tinggal di lingkungan sekitar kasus. Data faktor risiko diperoleh dari kuesioner yang diberikan kepada responden yaitu siswa SMPN 20 Depok, warga dan pesantren Petik. Responden dipilih secara cluster di SMPN 20 Depok, warga RT 01 dan RT 02 RW 01 dan pesantren Petik, dikarenakan lokasi tersebut merupakan lokasi yang berhubungan dengan kasus pertama yaitu SMPN 20 Depok, sehingga terdapat hubungan epidemiologi antara ketiga tempat ini. Populasi penelitian sebanyak 705 responden. Terdiri dari 318 kasus dan 387 kontrol. Waktu pelaksanaan penelitian ini adalah dari tanggal 26 November sampai tanggal 15 Desember 2019. Analisis data dilakukan secara univariat dan bivariat dengan menggunakan uji distribusi frekuensi dan uji chi square.

\section{HASIL DAN PEMBAHASAN}

Hasil analisis akan penulis paparkan sebagai berikut :

1. Distribusi kasus menurut umur

Tabel 1.1 Distribusi Kasus Hepatitis A Berdasarkan Kelompok Umur

\begin{tabular}{|c|c|c|c|c|c|c|c|c|}
\hline \multirow{2}{*}{$\begin{array}{c}\text { Usia } \\
\text { (tahun } \\
\text { ) }\end{array}$} & \multicolumn{2}{|c|}{ SMPN 20} & \multicolumn{2}{|c|}{$\begin{array}{c}\text { Pesantre } \\
\text { n }\end{array}$} & \multicolumn{2}{|c|}{ Warga } & \multirow{2}{*}{$\begin{array}{c}\text { Tota } \\
1\end{array}$} & \multirow{2}{*}{$\begin{array}{c}\text { Perse } \\
\text { ntase } \\
(\%)\end{array}$} \\
\hline & $\mathbf{N}$ & $(\%)$ & $\mathbf{N}$ & $\begin{array}{c}(\% \\
)\end{array}$ & $\mathbf{N}$ & $(\%)$ & & \\
\hline $1-4$ & 0 & 0 & 0 & 0 & 1 & 1,79 & 1 & 0,31 \\
\hline $5-14$ & $\begin{array}{c}21 \\
1\end{array}$ & $\begin{array}{c}84,7 \\
4\end{array}$ & 0 & 0 & $\begin{array}{l}1 \\
2\end{array}$ & $\begin{array}{c}21,4 \\
3\end{array}$ & 223 & 70,13 \\
\hline $15-44$ & 38 & $\begin{array}{c}15,2 \\
6\end{array}$ & 13 & 100 & $\begin{array}{l}4 \\
1\end{array}$ & $\begin{array}{c}73,2 \\
1\end{array}$ & 92 & 28,93 \\
\hline $45-54$ & 0 & 0 & 0 & 0 & 2 & 3,57 & 2 & 0,63 \\
\hline $\begin{array}{c}\text { Jumla } \\
\text { h }\end{array}$ & $\begin{array}{c}24 \\
9\end{array}$ & 100 & 13 & 100 & $\begin{array}{l}5 \\
6\end{array}$ & 100 & 318 & 100 \\
\hline
\end{tabular}

Proporsi terbesar kasus pada kelompok umur 15-44 tahun sebesar 73,21\% (92 kasus). Kasus termuda di RT 03 RW 02 pada anak usia 4 tahun $1,79 \%$ (1 kasus).

2. Distribusi kasus menurut jenis kelamin Tabel 1.2 Distribusi Kasus Hepatitis A Berdasarkan Jenis Kelamin Pada KLB

\begin{tabular}{|c|c|c|c|c|c|c|c|c|}
\hline \multirow{2}{*}{$\begin{array}{c}\text { Usia } \\
\text { (tahun) }\end{array}$} & \multicolumn{2}{|c|}{ SMPN 20} & \multicolumn{2}{|c|}{$\begin{array}{c}\text { Pesantre } \\
n\end{array}$} & \multicolumn{2}{|c|}{ Warga } & \multirow{2}{*}{$\begin{array}{c}\text { Tota } \\
1\end{array}$} & \multirow{2}{*}{$\begin{array}{c}\text { Perse } \\
\text { ntase } \\
(\%)\end{array}$} \\
\hline & $\mathbf{N}$ & $\begin{array}{c}(\% \\
)\end{array}$ & $\mathbf{N}$ & $\begin{array}{c}(\% \\
)\end{array}$ & $\mathbf{N}$ & $(\%)$ & & \\
\hline Laki-laki & $\begin{array}{c}13 \\
2\end{array}$ & $\begin{array}{c}53, \\
0\end{array}$ & 13 & 100 & $\begin{array}{l}3 \\
4\end{array}$ & 1,79 & 179 & 56,29 \\
\hline $\begin{array}{c}\text { Perempua } \\
n\end{array}$ & $\begin{array}{c}11 \\
7\end{array}$ & $\begin{array}{c}47, \\
0\end{array}$ & 0 & 0 & $\begin{array}{l}2 \\
2\end{array}$ & $\begin{array}{c}21,4 \\
3\end{array}$ & 139 & 43,71 \\
\hline Jumlah & $\begin{array}{c}24 \\
9\end{array}$ & 100 & 13 & 100 & $\begin{array}{l}5 \\
6\end{array}$ & 100 & 318 & 100 \\
\hline
\end{tabular}

Berdasarkan tabel di atas, proporsi laki-laki lebih besar daripada perempuan pada ketiga lokus tersebut, total persentase 3 lokus lakilaki sebanyak 56,29\% (179 kasus) dan persentase perempuan sebanyak 43,71 (139 kasus).

3. Distribusi kasus berdasarkan pemeriksaan antibody Hepatitis A Vyrus (HAV)

Tabel 1.3 Proporsi Pemeriksaan IgG dan IgM

\begin{tabular}{ccc}
\hline Hasil & Jumlah & Persentase \\
\hline Positif $(+)$ & 266 & 83,65 \\
Negatif $(-)$ & 52 & 16,35 \\
\hline Total & $\mathbf{3 1 8}$ & $\mathbf{1 0 0}$ \\
\hline
\end{tabular}

Berdasarkan tabel diatas, proporsi pemeriksaan IgG dan IgM kasus hepatitis A di Kota Depok dari 3 lokus terdata sebanyak 241 kasus yang melakukan pemeriksaan $\mathrm{IgG}$ dan IgM dengan rincian proporsi positif IgG dan IgM sebanyak 83,82\% (202 kasus), proporsi negatif $\mathrm{IgG}$ dan $\operatorname{IgM}$ sebanyak $16,18 \%$ (39 kasus) 
4. Distribusi kasus berdasarkan gejala klinis

Tabel 1.4 Distribusi Kasus

Berdasarkan Gejala Klinis

\begin{tabular}{lcc}
\hline & \multicolumn{2}{c}{ Kasus (N = 318) } \\
\cline { 2 - 3 } Gejala klinis & \multicolumn{2}{c}{ Sakit } \\
\cline { 2 - 3 } & Jumlah & \% \\
\hline Mata kuning & 135 & 42,45 \\
Kulit kuning & 57 & 17,92 \\
Air kencing seperti & 204 & 64,15 \\
teh & & \\
Sakit pada perut & 112 & 35,22 \\
kanan bawah & & 44,03 \\
Demam & 140 & 37,11 \\
Muntah & 118 & 43,08 \\
Sakit Kepala & 137 & 52,20 \\
Nafsu makan & 166 & 45,60 \\
berkurang & & 55,35 \\
Lelah & 145 & \\
Mual & 176 &
\end{tabular}

Berdasarkan tabel atas, dari 318 kasus gejala klinis hepatitis A, yang paling besar proporsinya adalah gejala air kencing seperti teh sebanyak 64,15\% (204 kasus), proporsi mual sebanyak 55,35\% (176 kasus), dan proporsi nafsu makan berkurang sebanyak $52,20 \%$ (166 kasus).

5. Distribusi kasus berdasarkan lokasi

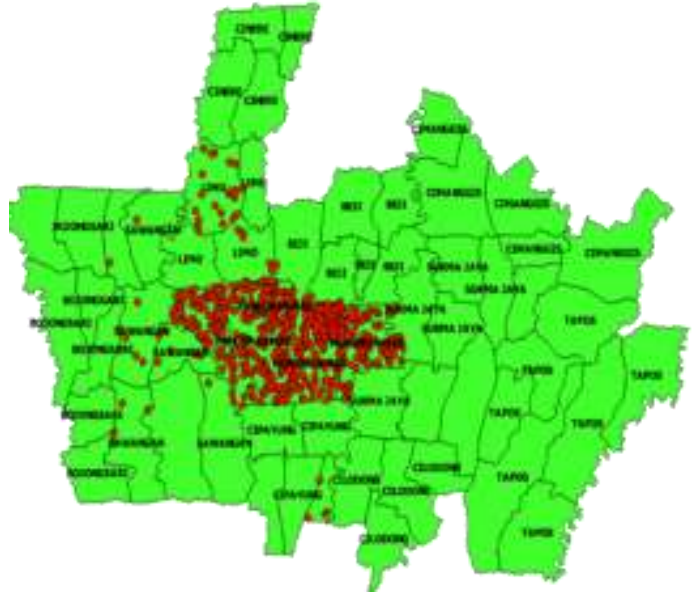

Gambar 1 : Distribusi Kasus

Berdasarkan gambar diatas dapat dilihat penyebaran kasus banyak terdapat di Kelurahan yang ada di Kecamatan Pancoran Mas, dan hanya beberapa penyebaran terjadi di kelurahan lainnya yang ini adalah siswa SMPN 20 Depok yang bertempat tinggal di luar kecamatan
Pancoran Mas seperti di kelurahan yang ada di Kecamtan Limo yang mana kelurahan tersebut berbatasan dengan kelurahan yang ada di Kecamatan Pancoran Mas. Kasus penyebaran sejumlah 318 dengan angka CFR 0\%. Kasus tersebar di 3 lokus yaitu SMPN 20 Depok, RT 01 dan RT 02/RW 01, RT 3/RW 02 Kelurahan Rangkapan Jaya dan pesantren Petik, dengan proporsi di SMPN 20 Depok sebesar 78\% (249 kasus), warga sebesar 18\% (56 kasus) dan pesantren Petik sebesar 4\% (13 kasus).

6. Distribusi kasus berdasarkan lokus

Tabel 1.6 Distribusi Kasus Hepatitis A Berdasarkan Lokus

\begin{tabular}{|c|c|c|}
\hline Lokus & Jumlah & Persentase \\
\hline SMPN 20 Depok & 249 & $78 \%$ \\
\hline Warga & 56 & $18 \%$ \\
\hline Pesantren Petik & 13 & $4 \%$ \\
\hline Total & 318 & 100 \\
\hline
\end{tabular}

Berdasarkan tabel di atas, sampai tanggal 2 Desember 2019 kasus yang dilaporkan di Dinas Kesehatan Kota Depok sejumlah 318 dengan angka CFR 0\%. Kasus tersebar di 3 lokus yaitu SMPN 20 Depok, RT 01 dan RT 02/RW 01, RT 3/RW 02 Kelurahan Rangkapan Jaya dan pesantren Petik, dengan proporsi di SMPN 20 Depok sebesar 78\% (249 kasus), warga sebesar 18\% (56 kasus) dan pesantren Petik sebesar 4\% (13 kasus)

7. Proporsi penyebaran kasus di SMPN 20 Depok

Tabel 1.7 Proporsi Penyebaran Kasus di SMPN 20 Depok Tahun 2019

\begin{tabular}{ccc}
\hline Kategori & Jumlah & Proporsi \\
\hline Kelas 7 & 90 & $36,14 \%$ \\
Kelas 8 & 92 & $36,95 \%$ \\
Kelas 9 & 56 & $22,49 \%$ \\
Guru & 9 & $3,62 \%$ \\
TU & 1 & $0,40 \%$ \\
Caraka & 1 & $0,40 \%$ \\
\hline Total & $\mathbf{2 4 9}$ & $\mathbf{1 0 0}$ \\
\hline
\end{tabular}


Berdasarkan tabel di atas, proporsi kasus hepatitis A di SMPN 20 Depok mayoritas pada kelas 8 sebanyak 36,95\% (92 siswa), diikuti proporsi kedua pada kelas 7 sebanyak $36,14 \%$ (90 siswa), proporsi ketiga pada kelas 9 sebanyak 22,49\% (56 siswa), sedangkan proporsi pada guru sebanyak 3,62\% (9 guru), dan proporsi TU dan Caraka masing-masing 0,40\% (1 TU dan 1 Caraka).

8. Distribusi kasus control berdasarkan penjamah makanan

Tabel 1.8 Distribusi Kasus Kontrol Berdasarkan Penjamah Makanan

\begin{tabular}{|c|c|c|c|c|c|c|c|c|}
\hline \multirow{3}{*}{$\begin{array}{c}\text { Penjama } \\
\text { h } \\
\text { Makanan }\end{array}$} & \multicolumn{5}{|c|}{$\begin{array}{c}\text { Siswa SMPN } 20 \text { Depok } \\
n=572\end{array}$} & \multirow[t]{3}{*}{ OR } & \multirow{3}{*}{$\begin{array}{c}95 \% \\
\text { CI }\end{array}$} & \multirow{3}{*}{$\begin{array}{c}P \\
\text { Valu } \\
e \\
\end{array}$} \\
\hline & \multicolumn{3}{|c|}{ Kasus } & \multicolumn{2}{|c|}{ Kontrol } & & & \\
\hline & & $\mathbf{N}$ & $\%$ & $\mathbf{N}$ & $\%$ & & & \\
\hline \multirow{4}{*}{ I } & Maka & 16 & 65,8 & 21 & 65,0 & 1,0 & $0,72-$ & 083 \\
\hline & $\mathrm{n}$ & 4 & 6 & 0 & 2 & 3 & 1,49 & 0,83 \\
\hline & Tidak & 85 & 34,1 & 11 & 34,9 & & & \\
\hline & & & & & & & & \\
\hline \multirow{4}{*}{ MA } & Maka & 16 & 67,2 & 24 & 75,5 & 0,6 & $0,45-$ & 003 \\
\hline & $\mathrm{n}$ & 6 & 1 & 4 & 4 & 6 & 0,97 & 0,03 \\
\hline & & 81 & 32,7 & 79 & 24,4 & & & \\
\hline & I laak & 81 & 9 & 19 & 6 & & & \\
\hline \multirow{4}{*}{$\mathrm{ME}$} & Maka & 16 & 65,8 & & 19,2 & 8,1 & $5,44-$ & \\
\hline & $\mathrm{n}$ & 2 & 5 & 62 & 0 & 1 & 12,1 & 0,00 \\
\hline & & & 34,1 & 26 & 80,8 & & & \\
\hline & Tidak & 84 & 5 & 1 & 0 & & & \\
\hline \multirow{4}{*}{ S } & Maka & 16 & 65,8 & 20 & 64,7 & 1,0 & $0,73-$ & 0 77 \\
\hline & $\mathrm{n}$ & 4 & 6 & 9 & 1 & 5 & 1,51 & $0, / 1$ \\
\hline & Tidak & 85 & 34,1 & 11 & 35,2 & & & \\
\hline & І Іак & os & 4 & 4 & 9 & & & \\
\hline \multirow{4}{*}{ B } & Maka & 17 & 69,6 & 24 & 75,2 & 0,7 & $0,51-$ & 014 \\
\hline & $\mathrm{n}$ & 2 & 4 & 3 & 3 & 5 & 1,11 & 0,14 \\
\hline & Tidak & 75 & 30,3 & 80 & 24,7 & & & \\
\hline & НИак & $1 J$ & 6 & 00 & 7 & & & \\
\hline \multirow{4}{*}{ AR } & Maka & 16 & 67,4 & 20 & 62,5 & 1,2 & $0,86-$ & 027 \\
\hline & $\mathrm{n}$ & 8 & 7 & 2 & 4 & 4 & 1,79 & 0,22 \\
\hline & Tidal & 81 & 32,5 & 12 & 37,4 & & & \\
\hline & ІІаак & 81 & 3 & 1 & 6 & & & \\
\hline \multirow{4}{*}{ MO } & Maka & 63 & 25,3 & 79 & 24,4 & 1,0 & $0,70-$ & 0.79 \\
\hline & $\mathrm{n}$ & 03 & 0 & & 6 & 5 & 1,57 & \\
\hline & Tidak & 18 & 74,7 & 24 & 75,5 & & & \\
\hline & поак & 6 & 0 & 4 & 4 & & & \\
\hline \multirow{4}{*}{ D } & Maka & 12 & 48,1 & 16 & 49,5 & 0,9 & $0,67-$ & 075 \\
\hline & $\mathrm{n}$ & 0 & 9 & 0 & 4 & 4 & 1,34 & $0, / 5$ \\
\hline & Tidak & 12 & 51,8 & 16 & 50,4 & & & \\
\hline & I 1dak & 9 & 1 & 3 & 6 & & & \\
\hline \multirow{4}{*}{$\mathrm{AL}$} & Maka & 14 & 59,8 & 18 & 58,2 & 1,0 & $0,76-$ & 061 \\
\hline & $\mathrm{n}$ & 9 & 4 & 8 & 0 & 9 & 1,55 & 0,01 \\
\hline & Tidak & 10 & 40,1 & 13 & 41,8 & & & \\
\hline & ІІаак & 0 & 6 & 5 & 0 & & & \\
\hline
\end{tabular}

Berdasarkan tabel di atas, proporsi penjamah makanan yang paling banyak dibeli siswa
SMPN 20 Depok pada kelompok kasus adalah kantin B (menjual nasi hokben, nasi goreng, macaroni kering, dimsum, spaghetti, burger, sosis lilit, sotang) sebanyak $69,64 \%$ (172 siswa yang membeli). Sedangkan proporsi penjamah makanan yang paling banyak dibeli siswa SMPN 20 Depok pada kelompok kontrol adalah kantin Ibu MA (menjual wafer, chiki, cokelat, air mineral, mie lidi, susu kotak) sebanyak 75,54\% (244 siswa yang membeli).

Hasil uji statistik menunjukan bahwa di kantin ME ( $p$ value 0,00; OR: 8,11\%; CI $5,44-12,12)$, artinya siswa yang membeli makanan di kantin ME beresiko 8,11 kali mengalami sakit dibandingkan dengan siswa yang tidak belanja di kantin ME. Makanan yang dijual Kantin ME adalah risol, cireng, nasi kuning, otak-otak goreng, dan pisang cokelat.

9. Proporsi berobat ke pelayanan kesehatan Tabel 1.9 Proporsi Berobat ke Pelayanan Kesehatan

\begin{tabular}{ccc}
\hline Yankes & Jumlah & Persentase \\
\hline Puskesmas & 46 & 18,47 \\
RS Pemerintah & 27 & 10,84 \\
RS Swasta & 71 & 28,51 \\
dokter/bidan/klinik & 48 & 19,28 \\
Tidak berobat & 57 & 22,89 \\
\hline Total & $\mathbf{2 4 9}$ & $\mathbf{1 0 0}$ \\
\hline
\end{tabular}

Berdasarkan tabel 1.9 di atas, proporsi berobat ke pelayanan kesehatan kasus hepatitis A di SMPN 20 Depok mayoritas ke RS Swasta sebanyak 28,51\% (71 kasus), proporsi berobat ke dokter/bidan/klinik sebanyak 19,28\% (48 kasus), proporsi berobat ke Puskesmas sebanyak 18,47\% (46 kasus), proporsi berobat ke RS Pemerintah/Negeri sebanyak 10,48\% (27 kasus), dan proporsi tidak berobat sebanyak $22,89 \%$ (57 kasus). 
10. Distribusi kasus berdasarkan waktu

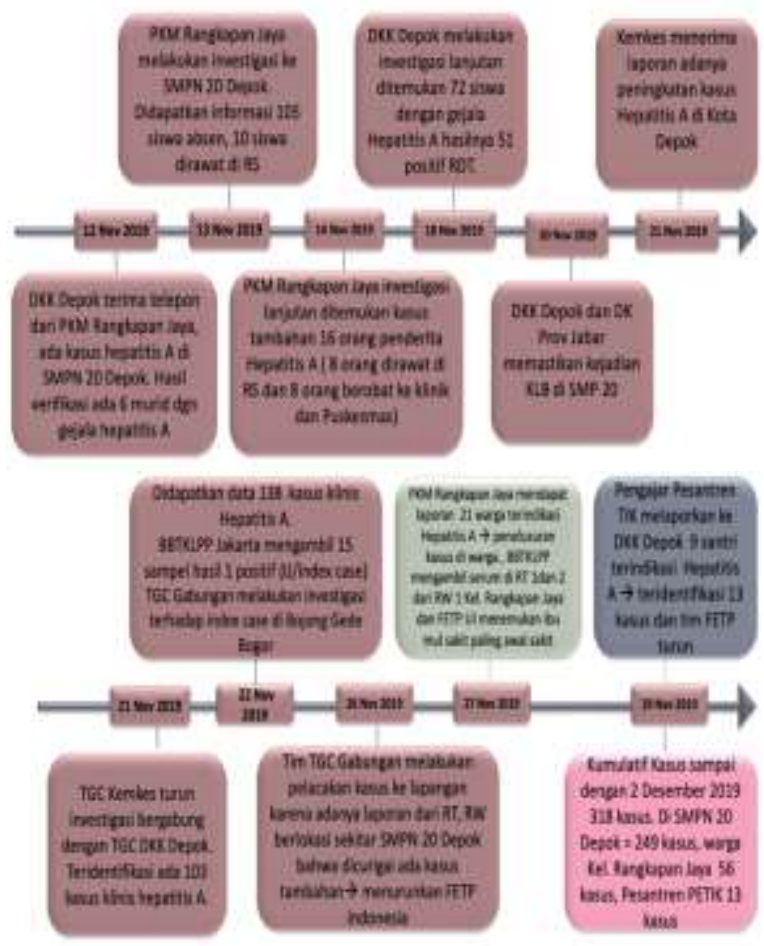

Berdasarakan gambar diatas dapat dilihat alur serta waktu terjadinya penyebaran kasus yang menyebabkan KLB di Kota
Depok Kecamatan Pancoran Mas tepatnya di Kelurahan Rangkapan Jaya yang mana kasus pertama dilaporkan oleh Puskesmas Rangkapan Jaya kepada Dinas Kesehatan Depok di SMPN 20 Depok pada tanggal 12 November 2019 terdapat 6 siswa yang menunjukan gejala klinis hepatitis A lalu keesokan harinya 13 November 2019 dilaporkan sebanyak 105 siswa absen sakit dan 10 orang dilaporkan dirawat di RS dengan gejala yang sama dengan 6 siswa dihari sebelumya, pada tanggal 14 November 2019 investigasi dilakukan oleh penulis dan tim FETP Universitas Indonesia bersama dengan tim puskesmas dan didapatkan lagi 18 siswa yang terindikasi hepatitis $\mathrm{A}$, dan hingga ditanggal 18 November 2019 didapatkan lagi 51 siswa yang positif dari 72 suspek, sehingga pada tanggal 10 November 2019 Pemerintah Kota Depok melalui Dinas Kesehatan menetapkan ini sebagai Kejadian Luar Biasa (KLB) Hepatitis A di Depok.

11. Analisis faktor risiko pada KLB Hepatitis A di Kota Depok

Tabel 1.11 Analisis Faktor Risiko Pada KLB Hepatitis A di Kota Depok Tahun 2019

\begin{tabular}{|c|c|c|c|c|c|c|c|c|}
\hline \multirow{2}{*}{\multicolumn{2}{|c|}{ Faktor Risiko }} & \multicolumn{2}{|c|}{ Kasus } & \multicolumn{2}{|c|}{ Kontrol } & \multirow{2}{*}{ OR } & \multirow{2}{*}{$95 \% \mathrm{CI}$} & \multirow{2}{*}{$\begin{array}{c}P \\
\text { value }\end{array}$} \\
\hline & & $\mathbf{n}$ & $\%$ & $\mathbf{n}$ & $\%$ & & & \\
\hline \multirow{2}{*}{$\begin{array}{c}\text { Pernah menggunakan } \\
\text { peralatan makan atau } \\
\text { minum secara } \\
\text { bersama/bergantian }\end{array}$} & Terpapar & 192 & 27,23 & 140 & 19,86 & \multirow[t]{2}{*}{2,68} & \multirow[t]{2}{*}{$1,95-3,69$} & \multirow[t]{2}{*}{0,00} \\
\hline & $\begin{array}{c}\text { Tidak } \\
\text { Terpapar }\end{array}$ & 126 & 17,87 & 247 & 35,04 & & & \\
\hline \multirow{2}{*}{ CTPS setelah BAB } & Terpapar & 98 & 13,90 & 38 & 19,79 & \multirow[b]{2}{*}{4,09} & \multirow[b]{2}{*}{$2,66-6,34$} & \multirow[b]{2}{*}{0,00} \\
\hline & $\begin{array}{c}\text { Tidak } \\
\text { Terpapar }\end{array}$ & 220 & 31,21 & 349 & 276,98 & & & \\
\hline \multirow[b]{2}{*}{ CTPS sebelum makan } & Terpapar & 103 & 32,39 & 58 & 14,99 & \multirow[b]{2}{*}{2,71} & \multirow[b]{2}{*}{$1,85-3,98$} & \multirow[b]{2}{*}{0,00} \\
\hline & Tidak & 215 & 67,61 & 329 & 85,01 & & & \\
\hline \multirow[b]{2}{*}{ Memotong kuku 1x/minggu } & Terpapar & 106 & 15,04 & 78 & 144,44 & \multirow[b]{2}{*}{1,98} & \multirow[b]{2}{*}{$1,38-2,82$} & \multirow[b]{2}{*}{0,00} \\
\hline & $\begin{array}{c}\text { Tidak } \\
\text { Terpapar }\end{array}$ & 212 & 30,07 & 309 & 117,05 & & & \\
\hline
\end{tabular}


Health Care : Jurnal Kesehatan 10 (1) Juni 2021 (194-203)

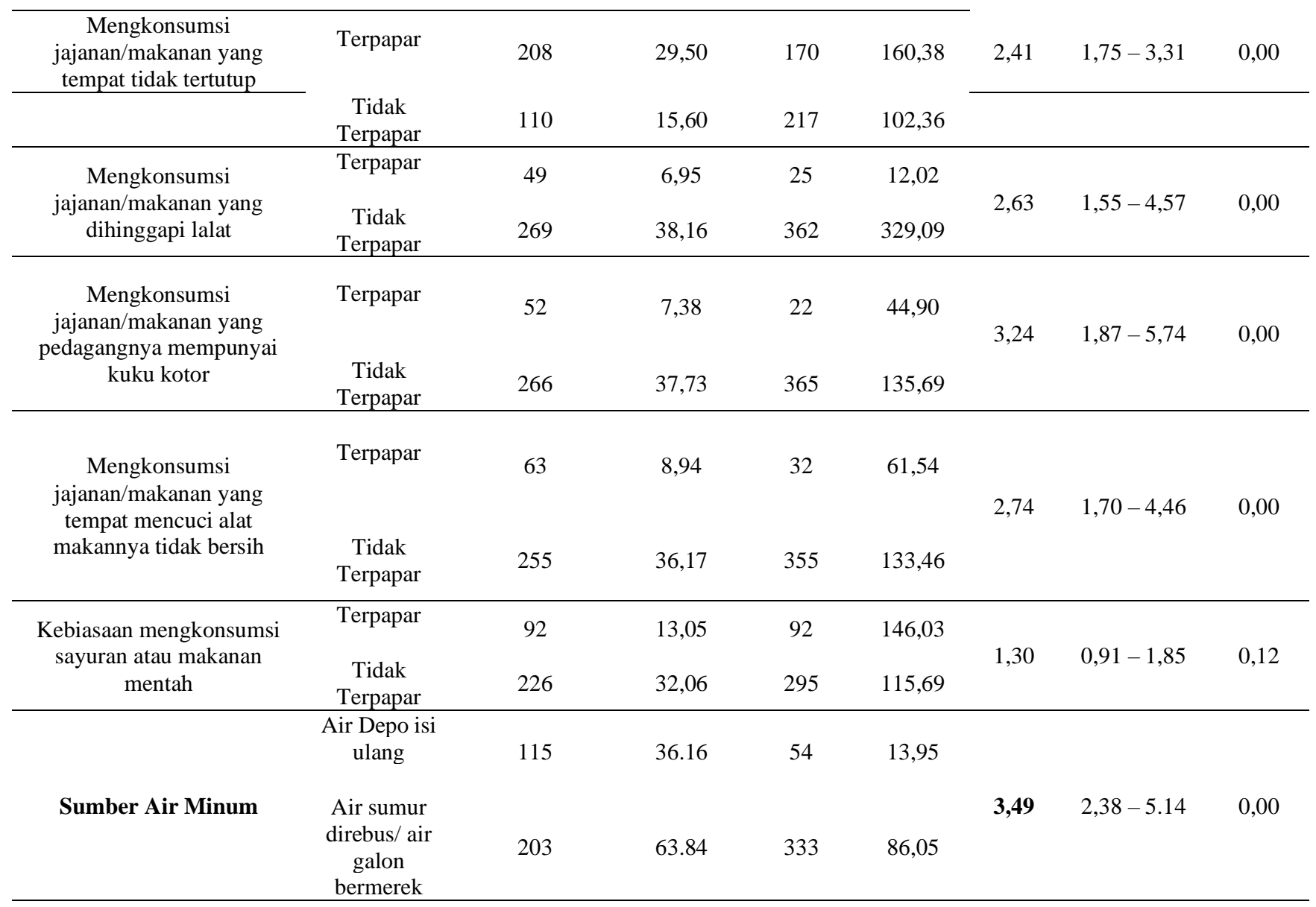

Berdasarkan hasil wawancara diketahui semua variabel perilaku di atas bermakna secara statistik untuk berisiko terkena Hepatitis A kecuali kebiasaan makan sayuran atau makanan mentah. Hasil analisis bivariate, faktor risiko paling besar adalah prilaku tidak CTPS setelah BAB dimana orang yang mempunyai prilaku tidak CTPS setelah BAB berisiko 4 kali Hepatitis A dibandingkan dengan orang berprilaku CTPS setelah BAB. Faktor risiko yang mempunyai risiko yang besar adalah sumber air minum isi ulang, dimana orang mengkonsumsi air minum dari depo isi ulang berisiko 3,49 kali Hepatitis A dibandingkan dengan orang yang sumber air minum berasal dari air gallon isi ulang bermerek/ air minum yang di masak.
12. Analisis multivariate factor risiko di Kota Depok

Tabel 1.12 Analisis Multivariat Faktor Risiko di Kota Depok (Model Akhir)

\begin{tabular}{|c|c|c|c|c|}
\hline No & $\begin{array}{l}\text { Variabel Faktor } \\
\text { Risiko }\end{array}$ & OR & $\begin{array}{c}95 \% \\
\text { CI }\end{array}$ & $\begin{array}{c}\mathbf{P} \\
\text { value }\end{array}$ \\
\hline 1 & Sumber Air Minum & 2,84 & $\begin{array}{c}1,92- \\
4,18\end{array}$ & 0,00 \\
\hline 2 & CTPS Sebelum Makan & 1,64 & $\begin{array}{l}1,09- \\
2,46\end{array}$ & 0,01 \\
\hline 3 & CTPS Setelah BAB & 3,04 & $\begin{array}{c}1,96- \\
4,72\end{array}$ & 0,00 \\
\hline 4 & $\begin{array}{l}\text { Peralatan Makan/Minum } \\
\text { Bersama }\end{array}$ & 2,08 & $\begin{array}{c}1,49- \\
2,89\end{array}$ & 0,00 \\
\hline
\end{tabular}


Berdasarkan hasil analisis multivariat di atas, disimpulkan bahwa perilaku pernah menggunakan alat makan/ minum bersama, yang berasal dari isi ulang bersiko Hepatitis A dan bermakna secara statistic.

Menurut WHO, orang yang belum pernah terpapar hepatitis A dan belum mendapatkan vaksinasi Hepatitis A akan dapat terinfeksi virus hepatitis $A$. salah satu penyebab paling umum terjadinya hepatitis A disebabkan dari makanan atau air yang terkontaminasi. Makanan atau air yang terkontaminasi tersebut dapat terjadi karena sanitasi lingkungan yang buruk (WHO, 2019). Penderita hepatitis A, terutama yang memiliki perilaku hidup bersih dan sehat yang masih rendah, berpotensi tinggi menjadi sumber penularan terhadap orang lain. Hal tersebut sangat mungkin terjadi mengingat penularan hepatitis A melalui fecal-oral (Rahmah \& Citra, 2016). Hasil investigasi KLB Hepatitis A di dua sekolah di Surabaya menunjukkan bahwa higiene sanitasi yang buruk di kantin sekolah, yaitu tidak ada fasilitas cuci tangan, air tercemar E.coli, jarak septic tank dengan sumur air yang dekat sebagai faktor risiko penularan virus Hepatitis A (Juniastuti et al., 2019).

Dari analisis diatas di simpulkan bahwa sumber air minum menjadi faktor risiko penyebab hepatitis A dikarenakan waraga sekolah baik murid, guru, pedagang dan bahkan warga setempat yang berdekatan dengan SMPN 20 Depok tersebut meminum air gallon isi ulang yang sama atau satu sumber karena satu-satunya yang paling dekat di daerah tersebut, yang mana air tersebut tim FETP dan BTLKPP Jakarta curigai sebagai sumber dikarenakan dari berbagai sumber seperti guru SMPN 20 serta beberapa warga dari hasil wawancara yang mengatakan rasa air aga berbeda dari biasa di beberapa hari sebelumnya, dan dari hasi observasi terlihat ridak hygienis dan sangat tidak memjaga kebersihan alat-alat,
Tidak CTPS sebelum makan, Tidak CTPS setelah BAB dan sumber air minum yang

walaupun saat pengamilan sampel dan pemeriksaan kadar ecoli masih diambang batas dan tidak ditemukan virus hepatitis $\mathrm{A}$ pada air tersebut dikarenakan samapel air yang diambil sudah berganti dan masa ingkubasi hepattits A yang lama.

CTPS sebelum makan dan CTPS setelah BAB menjadi faktor risiko terjadinya KLB pada SMPN 20 ini dikarenkan selain tidak tersedianya sabun di tempat cuci tangan/wastafel hingga toilet dan wc di sekolah ini, juga dikarenakan tidak tersedianya air yang cukup dan air yang mengalir, konfirmasi dari pihak sekolah yang mengatakan mesin pompa air yang sudah rusak dan belum diganti dari beberapa bulan belakangan. Peralatan makan/minum bersama menjadi faktor risiko dikarenakan pengakuan dari siswa yang sering makan cilok dan jajanan ringan lainnya serta minuman secara bersamaan melalui satu sedotan, hal ini lumrah dilakukan oleh siswa dikarenakan sebagai wujud dan bukti kesetiakawanan dan kebersamaan kepada sahabat agar terjalin hubungan yang lebih dekat.

Tindakan penanggulangan yang direkomendasikan dalam penanggulangan dan pencegahan KLB Hepatitis A antara lain sebagai berikut:

1. Melakukan Tindakan segera Tindakan terhadap kasus dalam rangka penyembuhan dan menghilangkan sumber penularan.

2. Melakukan pengobatan penyakit Hepatitis A secara adekuat.

3. Melakukan promosi kesehatan atau penyuluhan tentang penyakit Hepatitis A dan praktek hygiene yang baik.

4. Melakukan upaya pencegahan melalui imunisasi Hepatitis A.

5. Meningkatkann surveilan kasus berbasis laboratorium. 
6. Meningkatkan promosi kesehatan melalui program Perilaku Hidup Bersih dan Sehat (PHBS).

\section{SIMPULAN}

Faktor risiko yang mempengaruhi KLB Hepatitis A di Kota Depok adalah sumber air minum isi ulang, kebiasaan tidak CTPS sebelum makan, kebiasaan tidak CTPS setelah BAB dan prilaku makan/minum menggunakan peralatan bersama.

Untuk sumber KLB Hepatitis A di Kota Depok belum dapat diketahui dengan pasti akan tetapi penyebabnya diduga akibat paparan yang terjadi dalam waktu yang bersamaan (common source). Hal ini didukung dengan kurva epidemik yang berbentuk point source.

\section{UCAPAN TERIMA KASIH}

Penulis mengucapkan terima kasih kepada pihak Dinas Kesehatan Kota Depok dan warga Kelurahan Rangkapan Jaya dan siswa Pesantren Petik yang telah bersedia menjadi reponden.

\section{DAFTAR PUSTAKA}

Aryana, I. G. K., Ngurah, I. G., Putra, S., Karyana, I. P. G., Smf, B., Kesehatan, I., Fk, A., Udayana, U., \& Sanglah, R. (2014). Risk Factors of Hepatitis a Outbreak in Students At Elementary Schools. 79-84.

Harisma, F. B., Syahrul, F., Mubawadi, T., \& Mirasa, Y. A. (2018). Analisis Kejadian Luar Biasa Hepatitis a Di Sma X Kabupaten Lamongan Tahun 2018. Jurnal Berkala Epidemiologi, 6 Nomor 2, $112-121$. https://doi.org/10.20473/jbe.v6i2.2018.

Hikmah, N., Mahkota, R., Sariwati, E., \& Agus, D. (2018). 3.Faktor Risiko Terjadinya Kejadian Luar Biasa (KLB) Hepatitis A di Kabupaten Tangerang Tahun 2016 Risk Factor of Hepatitis A
7. Menyarankan pompa air diganti segera agar air tersedia dan bisa dialirkan

Virus (HAV) Outbreak at Tangerang District in 2016. Jurnal Epidemiologi Kesehatan Indonesia, 2(1), 1-6.

Juniastuti, Wahyuddin, D., Nihayatussa'adah, Amin, M., Yamani, L. N., Utsumi, T., Sustini, F., \& Lusida, M. I. (2019). Analysis of genetic and serology of hepatitis A virus infection during and after outbreak in two junior high schools in Surabaya, Indonesia. Journal of Medical Virology, 91(6), 1048-1055.

https://doi.org/10.1002/jmv.25403

Riskesdas, K. (2013). Riset Kesehatan Dasar (RISKESDAS) 2013. Laporan Nasional 2013, 1-384. https://doi.org/1 Desember 2013

Riskesdas, K. (2018). Hasil Utama Riset Kesehata Dasar (RISKESDAS). Journal of Physics A: Mathematical and Theoretical, 44(8), 1-200. https://doi.org/10.1088/17518113/44/8/085201

Suni, N. S. P. (2019). Tantangan dalam penanggulangan kejadian luar biasa (klb) penyakit hepatitis a di pacitan. Pusat Penelitian Badan Keahlian DPR RI, 11(14), 15.

WHO. (2019). Monitoring Health For The SDGs. In WHO Health Statistic (Vol. 1, Issue http://www.ghbook.ir/index.php?name

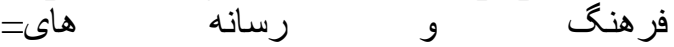
نوين\&option=com_dbook\&task=readon line\&book_id $=13650 \&$ page $=73 \& \mathrm{chkh}$ ashk=ED9C9491B4\&Itemid=218\&lan $\mathrm{g}=$ fa\&tmpl=component\%0Ahttp://ww w.albayan.ae\%0Ahttps://scholar.google .co.id/scholar?hl=en\&q=APLIKASI+P ENGENA 